\title{
Relationship between trace metal pollution and genetic polymorphisms in the biomonitor Nerita lineata from Peninsular Malaysia
}

\author{
Cheng Wan Hee, Yap Chee Kong, and Wong Ling Shing
}

\begin{abstract}
Genetic markers have long been identified as diagnostic tools to monitor marine pollution, as marine organisms exhibit genetic polymorphisms as adaptation and response towards environmental contaminants. This study aimed to determine the relationship between the heavy metal levels and the genetic polymorphisms of $N$. lineata, which were collected from six different mangrove areas in Peninsular Malaysia. Inter-Simple Sequence Repeat (ISSR) markers were applied for genetic polymorphism study in the snails while heavy metal analysis was carried out by using the atomic absorption spectrophotometer (AAS) for $\mathrm{Cd}, \mathrm{Cu}, \mathrm{Fe}, \mathrm{Ni}, \mathrm{Pb}$ and $\mathrm{Zn}$. The results showed that the clustering of genetic polymorphism was based on geographical influences while clustering of heavy metal levels was based on bioaccumulation of the metals by the snails. However, there were no relationship between clustering patterns of the genetic polymorphism and heavy metal levels of the snails. This indicated that the population genetic diversity of $N$. lineata is not a suitable biomarker for heavy metal.
\end{abstract}

Keywords: Nerita lineata, heavy metals, ISSR

\section{Introduction}

Marine coastal ecosystem is a rich habitat for many organisms and is vulnerable to various heavy metal contaminations from anthropogenic activities [1]. However, ecotoxicological studies should not be confined to the context of metal levels as the impact of the pollution is also revealed in the biological response of the organisms [15]. Marine organisms exhibit genetic polymorphisms due to adaptation and response towards environmental contaminants [3].

Cheng Wan Hee, Wong Ling Shing

INTI International University, Nilai,

Malaysia

Yap Chee Kong

Universiti Putra Malaysia,

Malaysia
Numerous researches were carried out to identify molecular biomarkers in marine pollution biomonitoring $[6,9]$. The mangrove snail, $N$. lineata, is widely found in the brackish coastal areas of Malaysia, Singapore and Indonesia. Researchers in this region has gained interest in $N$. lineata due to its potential as a good biomonitor for heavy metals [13, 14] but the relationships with the genetic composition is lacking in the literature.

In this study, the inter-simple sequence repeat (ISSR) technique was used for the analysis of genetic polymorphisms in the $N$. lineata. In recent years, ISSR technique has been incorporated in marine pollution studies to relate genetic variations with environmental pollutants [8, 11]. The ISSR technique has been proposed to be a simpler and more effective choice of genetic diversity studies compared to its counterparts such as allozyme and RAPD (Random Fragment Length Polymorphism) [4, 5, 8, 10]. The objective of this study is to investigate the relationship between the heavy metal levels and the genetic polymorphisms of $N$. lineata collected from 6 sites in mangrove areas of Peninsular Malaysia.

\section{Materials and Methods}

\section{A. Sample collection}

The snail samples were collected from 6 sites of Peninsular Malaysia (Jetty to Pulau Ketam, Sg. Janggut, Kpg. Pasir Puteh, Kpg. Sg. Ayam, Kpg. Sg. Melayu, Lukut). After collection, the snails were dissected and muscle tissues taken from the snails for heavy metal analysis and ISSR analysis. Samples were then stored at $-20^{\circ} \mathrm{C}$ and $-80^{\circ} \mathrm{C}$ for heavy metals and ISSR analysis, respectively.

\section{B. Metal Analysis}

Dried muscle tissues were digested in concentrated nitric acid (AnalaR grade, BDH 69\%) based on the 
Proc. of the Seventh International Conference On Advances in Applied Science and Environmental Engineering - ASEE 2017. Copyright $\odot$ Institute of Research Engineers and Doctors. All rights reserved.

ISBN: 978-1-63248-125-2 doi: 10.15224/ 978-1-63248-125-2-03

procedures by Yap et al. [13] and analyzed for $\mathrm{Cd}, \mathrm{Cu}$, $\mathrm{Fe}, \mathrm{Ni}, \mathrm{Pb}$ and $\mathrm{Zn}$ by using an air-acetylene PerkinElmer ${ }^{\mathrm{TM}}$ flame Atomic Absorption Spectrophotometer (AAS) Model Analyst 800. The analysis was conducted in triplicates.

\section{Genetic Analysis}

The protocol of DNA extraction was modified from Barker et al. [2] using a series of phenol and chloroform extraction. Out of 59 tested primers, only 8 of the primers were selected and optimized for PCR (Table 1). The PCR product was then analysed with gel electrophoresis with $1.5 \%$ agarose gel (First Base, biotechnology grade) in $1 \times$ TBE running buffer, at $70 \mathrm{~V}$ for $90 \mathrm{~min}$ where the end product of the gel were viewed under UV light.

Table 1. ISSR primer and sequence in this study.

\begin{tabular}{llll}
\hline No & Primer & Primer Sequence & $\begin{array}{l}\text { Annealing } \\
\text { Temperature } \\
\left({ }^{\circ} \mathrm{C}\right)\end{array}$ \\
\hline 1 & IT3 & 5' CACACACACACACACAAG 3' & $60.7{ }^{\circ} \mathrm{C}$ \\
2 & SAS1 & 5' GTGGTGGTGGTGGC 3' & $65.7{ }^{\circ} \mathrm{C}$ \\
3 & SAS3_1 & 5' GAGGAGGAGGAGGC 3' & $62.9{ }^{\circ} \mathrm{C}$ \\
4 & SAS3_2 & 5' GTGGTGGTGGC 3' & $59.1{ }^{\circ} \mathrm{C}$ \\
5 & SAS3_3 & 5' ACACACACACACACACC 3' & $62.7{ }^{\circ} \mathrm{C}$ \\
6 & SAS3_4 & 5' AGAGAGAGAGAGAGAGY 3' & $58.1{ }^{\circ} \mathrm{C}$ \\
7 & SAS3_5 & 5' CACACACACACARG 3' & $56.3{ }^{\circ} \mathrm{C}$ \\
8 & SAS3_6 & 5' CCACCACCACCACCA 3' & $66.6{ }^{\circ} \mathrm{C}$ \\
\hline
\end{tabular}

\section{Data Analysis}

Software POPGENE version 1.31 was used to contruct the Unweighted Pair Group Method with Arithmetic Mean (UPGMA) dendrogram [7] to illustrate the relationship among populations. Cluster analysis (based on Single Linkage Euclidean distances) using statistical software STATISTICA for Windows (StatSoft, Inc., USA, 1995, Version 8.0) for total trace metals in the tissues of the snails were also constructed for comparison.

\section{Results and Discussion}

The of UPGMA dendrogram (Figure 1) depicted the genetic polymorphisms of the snails in 3 main clusters: the first cluster consisting of Jetty to Pulau Ketam and Sg. Janggut from Klang (Selangor); the second cluster consisting of Sg. Ayam and Kpg. Pasir Puteh from industrial areas of Johore; third cluster consisting of Kpg. Sg. Melayu (Johore) and Lukut (Negeri Sembilan). The cluster analysis (Figure 2) of 6 total heavy metal concentrations in the soft tissues of the snails is divided into 3 main clusters. The first cluster consisted of Kpg. Sg. Melayu and Lukut. The second cluster consisted of Jetty to Pulau Ketam, Sg. Ayam and Kpg. Pasir Puteh. The last cluster consisted of solely $\mathrm{Sg}$. Janggut.

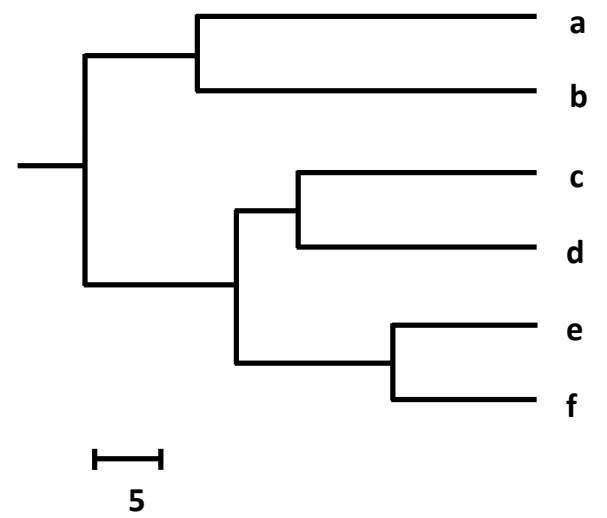

Figure 1: Dendrogram Based Nei's (1972) Genetic distance: Method = UPGMA for Nerita lineata collected from 6 sites. $(\mathrm{a}=$ Jetty to Pulau Ketam; b= Sg. Janggut; c= Sg. Ayam; d=Kpg. Pasir Puteh; e= Kpg. Sg. Melayu; $\mathrm{f}=$ Lukut

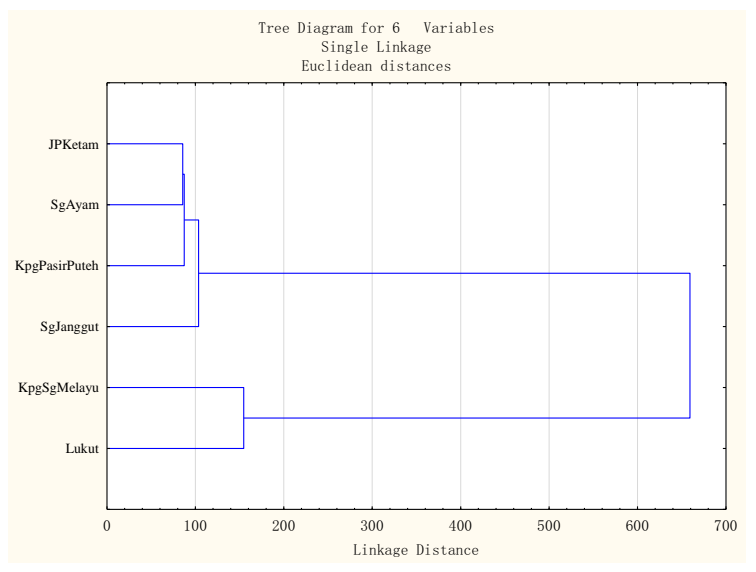

Figure 2: Cluster analysis on Nerita lineata based on 6 metals collected from 6 sites.

The clustering pattern of genetic polymorphisms and the clustering patterns of heavy metal concentrations showed no correlations except Kpg. Sg. Melayu and Lukut. The UPMA dendrogram (Figure 1) showed clustering based on geographical where each cluster is collected from the same area (first and second 
Proc. of the Seventh International Conference On Advances in Applied Science and Environmental Engineering - ASEE 2017. Copyright $\odot$ Institute of Research Engineers and Doctors. All rights reserved.

ISBN: 978-1-63248-125-2 doi: 10.15224/ 978-1-63248-125-2-03

cluster) or with same local activities (third cluster). On the contrary, the clustering of heavy metals based on metal pollution level on the sites where the first consisted of sites that showing minimal pollution sources while the second cluster consisted of some of the most polluted sites in Malaysia [12]. This suggested that the genetic polymorphisms of the snails are more likely influenced by geographical and environmental factors other than bioaccumulation of metals by the snails. The present results do not support the use of population genetic diversity of $N$. lineata as a population-level biomarker for heavy metal.

\section{Conclusion}

This study concluded that there were no relationships between genetic polymorphisms and heavy metals levels of the $N$. lineata from the studied sites. However, more studies are needed to validate the relationship of the genetic variation in the snails and the the pollution level of heavy metals.

\section{Acknowledgment}

The authors wish to acknowledge the financial support provided through the Research University Grant Scheme (RUGS), [Vote no.: 9199791], by Universiti Putra Malaysia.

\section{References}

[1] L.H. An, B.H. Zheng, L.J. Wang, Y.Q. Zhang, H. Chen, X.R. Zhao, L. Zhang, and $\mathrm{K}$ Lei, "Biomarker responses and genotoxicity in the mud snail (Bullacta exarata) as indicators of coastal contamination," Marine Poll. Bull., Vol. 64(2), pp. 303309, 2012.

[2] C.S. Barker, L. Medrano-Gonzalez, J. Calambokidis, A. Perry, F. Pichler, H. Rosenbaum, J.M. Straley, J. Urrban-Ramirez, M. Yamaguchi, and O. von Ziegesar, "Population structure of nuclear and mitochondrial DNA variation among humpback whales in the Notrh Pacific," Mol. Ecol., Vol. 7, pp. 695-707, 1998.

[3] N. Basu, J.M. Goodrich, and J. Head, "Ecogenetics of mercury: From genetic polymorphisms and epigenetics to risk assessment and decision-making," Environ. Toxicol. and Chemistry, Vol. 33(6), pp. 1248-1258, 2014.

[4] M. Carla de Aranzamendi, R. Sahade, M. Tatián,and M.B. Chiappero, "Genetic differentiation between morphotypes in the Antarctic limpet Nacella concinna as revealed by inter-simple sequence repeat markers," Mar Biol, Vol. 154: 875-885, 2008.

[5] M. Casu, G.A. Rivera-Ingraham, P. Cossu, T. Lai, D. Sanna, G.L. Dedola, R. Sussarellu, G. Sella, B. Cristo, M. CuriniGalletti, J.C. Garc1'a-Go'mez, and F. Espinosa, "Patterns of spatial genetic structuring in the endangered limpet Patella ferruginea: Implications for the conservation of a Mediterranean endemic," Genetica, Vol. 139, pp. 1293-1308, 2011.
[6] P.K.S. Lam, "Use of biomarkers in environmental monitoring," Ocean Coast. Manag., Vol. 52(7), pp. 1-7, 2009.

[7] M. Nei, and W.H. Li, "Mathematical model for studying genetic variation in terms of restriction endonucleases," Proceedings of the National Academy of Sciences, Vol. 76, pp. 5269-5273, 1979.

[8] K.K. Nkongolo, S. Gervais, P. Michael, and Y. Zhou, "Comparative analysis of inter simple sequence repeats and simple sequence repeats markers: Genetic analysis of Deschampsia cespitosa populations growing in metal contaminated regions in Canada," Am. J. Biochem. Biotechnol., Vol. 10(1), pp. 69-80, 2014.

[9] A. Sarkar, D. Ray, A.N. Shrivastava, and S. Sarker, "Molecular biomarkers: Their significance and application in marine pollution monitoring," Ecotoxicology, Vol. 15, pp. 333-340, 2006.

[10] S. Siddiquee, S.G. Tan, U.K. Yusuf, N.H.N. Fatihah, and M.M. Hasan, "Characterization of Malaysian Trichoderma isolates using random amplified microsatellites (RAMS)," Mol. Biol. Rep., Vol. 39, pp. 715-722, 2012.

[11] S. Sukumaran, and A. Grant, "Effects of genotoxicity and its consequences at the population level insexual and asexual Artemia assessed by analysis of inter-simple sequence repeats (ISSR)," Mutat. Res., Vol. 757, pp. 8- 14, 2013.

[12] C. K. Yap, A. Ismail, S.G. Tan, and H. Omar, "Concentration of $\mathrm{Cu}$ and $\mathrm{Pb}$ in the offshore and intertidal sediments of the west coast of Peninsular Malaysia," Environ. Int., Vol. 28, pp. 467479, 2002.

[13] C.K. Yap, W.H. Cheng, A. Ismail, A.R. Ismail, and S.G. Tan, "Biomonitoring of heavy metal $(\mathrm{Cd}, \mathrm{Cu}, \mathrm{Pb}$, and $\mathrm{Zn})$ concentrations in the west intertidal area of Peninsular Malaysia by using Nerita lineata," Toxicology \& Environ. Chem., Vol. 91, pp. 29-41, 2009.

[14] C.K. Yap, S. Mohd Ruszaidi, W.H. Cheng, and S.G. Tan, "Heavy-metal concentrations in the mangrove snail, Nerita lineata and surface sediments collected from Klang river estuary, Selangor, Malaysia," J. Sustain. Sci. Manage., Vol. 5, pp. 1-12, 2010.

[15] C.K. Yap, C.M. Chong, and S.G. Tan, Allozyme polymorphisms in horseshoe crabs, "Carcinoscorpius Scorpiusauda, collected from polluted and unpolluted intertidal areas in Peninsular Malaysia," Environ. Monit. Assess., Vol. 174, pp. 389-400, 2011. 